\section{Høyt forbruk av antibiotika ved akutt hoste}

\author{
Over halvparten av pasienter med akutt hoste får skrevet ut antibiotika. \\ Det viser en stor europeisk undersøkelse. Norske allmennleger er blant \\ dem som skriver ut minst.
}

I undersøkelsen, som ble gjennomført i allmennpraksis i 13 europeiske land, ble antibiotika skrevet ut til $53 \%$ av voksne med akutt hoste eller andre tegn på nedre luftveisinfeksjon (1). Forskrivningsfrekvensen varierte fra $21 \%$ til $88 \%$ mellom landene. Til sammen 3402 pasienter ble rekruttert til undersøkelsen, som er den største i sitt slag som noen gang er blitt gjennomført.

- Symptomer og kliniske funn kunne ikke på noen måte forklare forskjellene i antibiotikaforskrivning. Tvert imot var det slik at forskjellene mellom landene ble større når man tok hensyn til kliniske funn og symptomenes omfang og alvorlighetsgrad. Da fant man at pasienter i Slovakia, Italia, Ungarn, Polen og Wales hadde dobbelt så stor sannsynlighet for å få skrevet ut antibiotika som gjennomsnittet i de europeiske landene, mens den tilsvarende sannsynligheten for pasienter fra Belgia, Sverige og Norge var mindre enn en firedel, sier Hasse Melbye, professor i allmennmedisin ved Universitetet i Tromsø.

- Pasientene rapporterte symptomer og deres alvorlighetsgrad $i$ en dagbok i fire uker. Tilfriskningen var tilnærmet lik i de 13 landene og dermed ikke nevneverdig påvirket av forskjellene $\mathrm{i}$ antibiotikabruk.

Undersøkelsen viser at det bør være mulig å begrense antibiotikaforskrivningen betraktelig til pasienter med akutt hoste, uten å sette pasientenes sikkerhet på spill.

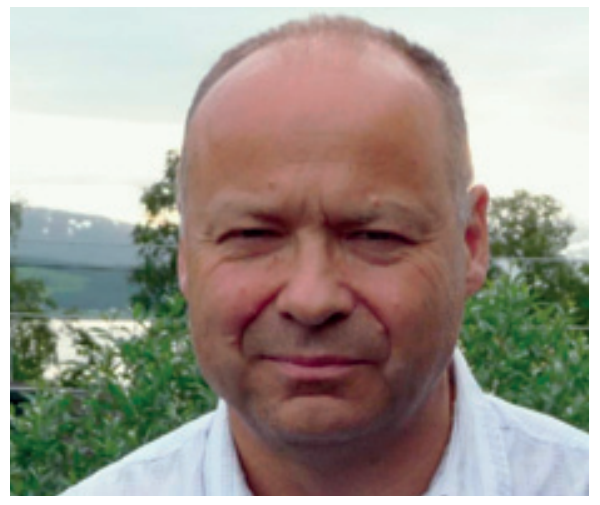

Hasse Melbye. Foto privat

Det er også helt nødvendig for å bekjempe den økende antibiotikaresistensen man observerer blant luftveispatogene bakterier, sier Melbye.

\section{Erlend Hem}

erlend.hem@medisin.uio.no

Tidsskriftet

\section{Litteratur}

1. Butler CC, Hood K, Verheij T et al. Variation in antibiotic prescribing and its impact on recovery in patients with acute cough in primary care: prospective study in 13 countries. BMJ 2009; 338: b2242.

\section{Ordforklaringer:}

GRACE (Genomics to combat Resistance against Antibiotics in Community-acquired lower respiratory tract infections in Europe) omfatter 14 allmennmedisinske forskningsnettverk i 13 europeiske land: Belgia, Finland, Tyskland, Nederland, Ungarn, Italia, Norge, Polen, Slovakia, Spania, Sverige, Wales og England.
Er du i ferd med å publisere eller har du nylig publisert i et internasjonalt tidsskrift? Send tips til erlend.hem@medisin.uio.no www.tidsskriftet.no/norskforskning

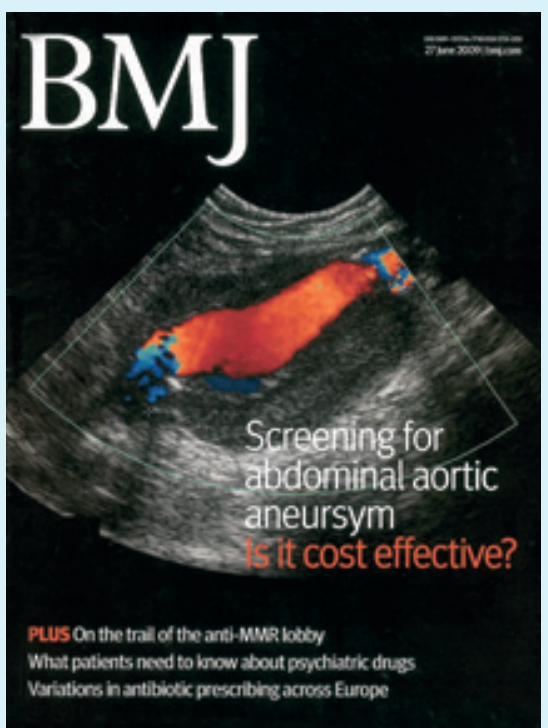

Artikkelen ble publisert 23.6. 2009 i BMJ (www.bmj.com), som regnes som en av de «fem store» innen medisinsk publisering ved siden av New England Journal of Medicine, JAMA, Annals of Internal Medicine og The Lancet 